\title{
НУМЕРАТИВИ ЯК ПСИХОЛІНГВАЛЬНА ОЗНАКА ПОЕТИКИ ШІСТДЕСЯТНИКІВ
}

\author{
ІННА ПАВЛОВА \\ Харківський національний педагогічний університет імені Г. С. Сковороди, \\ Харків - Україна
NUMERATYWY JAKO CECHA PSYCHOLINGWISTYCZNA POETYKI GENERACJI LAT 60-TYCH

\author{
INNA PAWŁOWA \\ Charkowski Narodowy Uniwersytet Pedagogiczny im. H. Skoworody, \\ Charków — Ukraina
}

STRESZCZENIE. W artykule przedstawiono poetów lat 60 -ch XX wieku I. Dracza i L. Kostenko jako osobowości językowe, należące do różnych typów psychologicznych ekstrawertyków i introwertyków. Wniosek prognostyczny co do psychotypu wysnuto na podstawie analizy swoistego funkcjonowania liczebników w tekstach poetyckich I. Dracza i L. Kostenko w ich szerokiej reprezentacji jako klasy leksykalno-gramatycznej. Scharakteryzowano współdziałanie gramatyki i poetyki liczebnika na różnych płaszczyznach oraz kształtowanie się jego znaczenia pragmatycznego.

\section{NUMERATIVES AS A PHYCHOLOGICAL LINGUISTIC FEATURE OF THE POETRY BY THE THAW AUTHORS}

\section{INNA PAVLOVA \\ H. S. Skovoroda Kharkiv National Pedagogical University, Kharkiv — Ukraine}

ABSTRACT. The paper is devoted to the poets of the Thaw, I. Drach and L. Kostenko, as language personalities, belonging to different psychological types - extraverts and introverts. The prognostic conclusion as for the poetic psychological type is based on the analysis of specific features of numerals as a lexical-grammatical class of words functioning in poetic texts by I. Drach and L. Kostenko. The research characterizes complex varied interaction of the numerals grammar and poetics, the specifics of forming their pragmatic meaning.

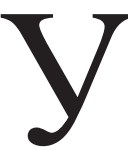

мовознавчій літературі набули поширення різні терміни на позначення тих чи тих одиниць, що виражають кількість, один із них - нумератив. Нумеративи - це засоби мови, що виражають точні числові значення, які можуть бути співвіднесені з елементами натурального ряду чисел. Центральне місце серед цих одиниць посідають кількісні числівники ${ }^{1}$ як виразники абстрактно-математичної кількості.

Числівник належить до закритої лексичної системи слів, його вважають такою частиною мови, що має незначний вихід у прагматичну сферу власне через обмеженість семантичного значення. У різних ракурсах й у різний час числівник активно досліджували такі зарубіжні й вітчизняні науковці, як I. Боду-

${ }^{1}$ В. В. Акуленко, С. А. Швачко, Е. И. Бекреева, Категория количества в современных европейских языках, Київ 1990, с. 18. 
ен де Куртене, П. Флоренський, І. Мельчук, Ю. Шевельов, А. Супрун, Ю. Апресян, Н. Арутюнова, М. Всеволодова, А. Вежбицька, В. Акуленко, К. Городенська, Г. Арполенко, К. Щербатюк, Т. Лукінова, С. Жаботинська та ін. Символіка числівника також має свою традицію вивчення (А. Лосєв, В. Топоров, Н. Арутюнова, Дж. Джинджихадзе та ін.), але специфіка його функціонування в художньому мовленні сучасних майстрів слова, з огляду на схильність до певного психотипу, залишається недослідженою, натомість числівник є носієм авторської суб'єктивно-об'єктивної оцінки, а отже, є активною стилістемою, маркером ідіостилю письменника, виразником його психотипу.

Актуальність дослідження полягає в особливій зацікавленості мовознавців проблемою функціонування мовних одиниць у поетичних текстах визначних мовних особистостей, до яких належать поети-шістдесятники, з огляду на їхню схильність до певного психотипу.

Останнім часом увагу лінгвістів привертає питання своєрідності мовного вираження творчого задуму і його зумовленості психікою письменника. Мовний матеріал залежить як від внутрішнього світу письменника, на який впливають культурно-історичні та соціальні фактори, так і від психологічних особливостей поета.

Л. Лисиченко актуалізувала питання, що було поставлено ще у працях В. фон Гумбольдта, О. Потебні та інших учених, щодо необхідності дослідження “співвідношення мовного і психічного світів письменника, оскільки ці дві величини знаходяться у тісній взаємодії. Для цього створені і психологічні передумови в багатьох фундаментальних працях із психології, яка виділила й дослідила низку психічних властивостей і рис, що характеризують особистість і виявляють психічні типи людей"2.

Мета цієї наукової розвідки - виокремити специфіку репрезентації нумеративів у художніх текстах поетів-шістдесятників як мовних особистостей з урахуванням їхньої приналежності до відповідного психотипу. Поставлена мета передбачає виконання таких завдань: 1) розглянути й описати стан дослідження художнього мовлення поетів-шістдесятників у сучасному українському мовознавстві; 2) окреслити характерні риси психологічних типів; 3) визначити домінантні числівникові форми в поетичних текстах; 4) з'ясувати прагматичну значущість числівників, їхнє функціональне навантаження 3 огляду на приналежність поетів до певного психотипу.

У мові відмінності психічних типів виявляються в характері лексичного матеріалу, частотності певних слів, що стають ключовими у творі поета. Так, в інтровертів значне місце посідає лексика на позначення внутрішнього стану, назви просторових понять виражаються цілими блоками без деталізації ландшафту, лексеми переважно виступають не як предмет зображення, а як засіб характеристики інших предметів і явищ. Поет-екстраверт змальовує світ, інтроверт же зображує свої переживання від вражень про світ.

До найбільш виразних і талановитих представників шістдесятництва традиційно відносять Л. Костенко й І. Драча, поетичні тексти яких репрезентують індивідуальну техніку у використанні мови, засвідчують наявність значної кількості числівників порівняно з іншими поетами, тому саме їхні твори й були обрані для аналізу.

2 Л. Лисиченко, Мова: психологічний тип поета, [в:] Мовознавство: Тези та повідомлення III міжнародного конгресу украӥністів, Харків 1996, с. 234. 
Числівник, що функціонує в поезії шістдесятників, є виразною демонстрацією культурно-історичних горизонтів поетів, віддзеркалює елементи автобіографій. У поезії відчутно вплив символіки числа, його сакралізації, міфологізації й ідеологізації. У поезії шістдесятників набуває специфічного вираження не лише поняття числа, але й ширше - категорія кількості, виміру, величини. I. Драч висловлює думку всіх шістдесятників, зауважуючи, що час його епохи ие час панування числа, хоча поет і наголошує, що слово - надчислова категорія, тобто вище числа стоїть лише слово як таке, порівн.: Перфокарто! Ніжні рожеві груди твої / Пробива перфоратор - вірний лицар числа. / А я ж на них слово посію, слово... (Вірші на перфокартах) $)^{3}$.

У поетичних текстах I. Драча наявна велика кількість числівників, що належать до різних лексико-семантичних розрядів. Числівникові форми, що виконують свою безпосередню функцію номінації кількості або порядку при лічбі, складають близько половини всіх слововживань: I дихають на мене три біди: / Одна біда чорнюща чорнота, / A друга дивна - чиста і свята, / A третя зводить руку до чола... (Причетність планетарна $)^{4}$; Пане генерале! Для вашої армії / Навантажено тринадиять составів / Модернізованих мозків типу "Дегенерат”... (Балада ДНК - дезоксирибонуклеїнової кислоти) ${ }^{5} ;$... Вона ж його так вичікує, аж навшпиньки хвилі встає / Та шепоче, щзоб не забутися: Уран - двісті тридиять вісім (Поліська легенда) 3 стонадцятьма окулярами? (Розмова з бабою історією) ${ }^{7}$ та ін.

Поет намагається все виміряти, пронумерувати, точно схарактеризувати, укласти в систему, життєву картину за точними кількісними й числовими характеристиками. І. Драч за допомогою всіх типів числівників “підраховує” гроші, порівн.: Тоді б поменшало пихатих, / Коли б за ваші дифірамби / По трудодню за день писати, / Так, як в середньому колгоспі, / Сипнути кілограм пшениці, / Та щзе копійок тридиять... Досить! / О короїди, вічні й ниці! (Пам'яті I. Вишенського $)^{8}$, Марія Яремівна посміхається на всі свої срібні зуби / (Виділили в профкомі карбованців десь шістдесят)... (Марія з України - № 62276: від Освенціму до Чорнобильської атомної) ${ }^{9}$, вимірює явища природи: Мороз тріскотів десь під градусів тридцять. / Небо у зорях, як в ранок, ятриться (Січнева балада 1924 року) $)^{10}$, тиск: Тиск 230 в білих халатах, / Пульс мерехтливий, / Мов подих метелика (Іберійське тяжіння) ${ }^{11}$, час: Людина вже звикає / Визначати спадкоємність. Намагання / Запрограмувати креслення білка! / Штучні організми через десять літ! / Біологія ракетно вирвалась в політ (Балада ДНК - дезоксирибонуклеїнової кислоти) ${ }^{12}$; Питаєте, чому я все мовчу, / П'ятнадцять літ лютую німотою, / П'ятнадцять літ я корчусь від плачу. / Що ж! Тільки плач на мене йде ордою (Мовчанка Стефаника) ${ }^{13}$, конкретизує вік людини, пов'язаний із відповідними подіями життя, ії станом, порівн.: Зазирне у люстерко: гарна, / Ні дефекту, самісінький извіт, / Не прилипла ніяка догана /

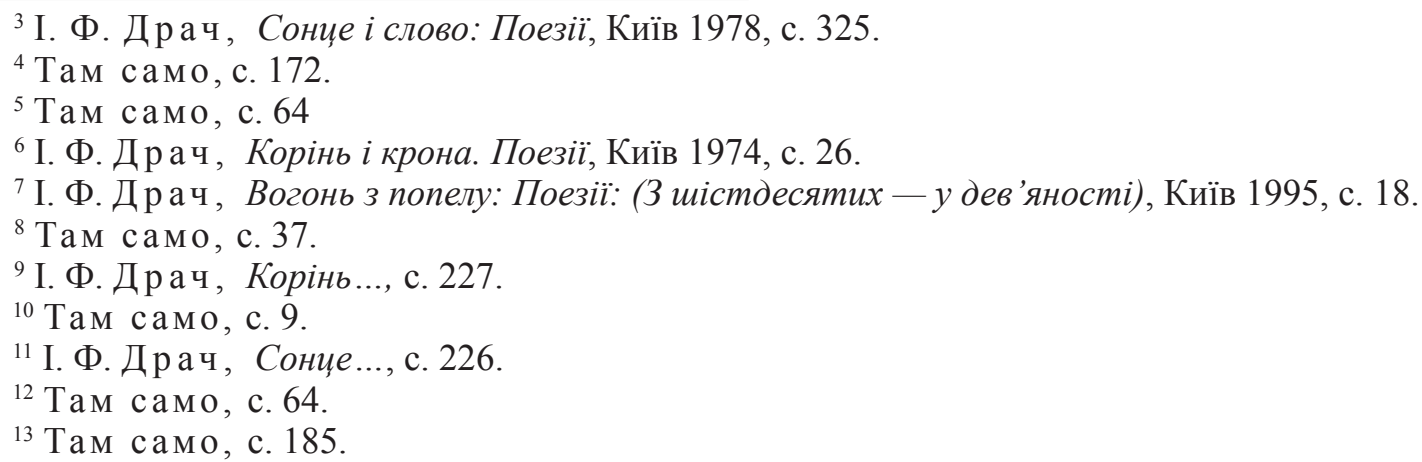


У ї дев'ятнадцять літ (Дефектоскопістка) ${ }^{14}$; Я сивіти почав у двадцять n'ять / Од тої хати, од скорботи тої (Ніж у Сонці) ${ }^{15}$; Та все він вичікував. Під сорок п'ять. / Морози гули, а під березень спали, / I сонцее на кремені гралось в опали. / I чув він - вже крижі старечо болять (Снісейський характер) ${ }^{16}$; Іване мій Семеновичу, рідний, / Біжать літа крізь пальиі, як вода, / А ви ж такий красивий, многоцвітний, / Сімдесят п'ять: це ж не роки - года! (Іванові Семеновичу Козловському на сімдесятип 'ятиріччя) ${ }^{17}$, вимірює простір: Вода з двохсот метрів сторчма тут впаде, — / Черемхове займище (Черемхове займище) ${ }^{18}$, Просто - хочеться дум твоїх, / Яким непідвладні пальиі, / Яким тридцять три горизонти сняться (Тихий диптих) ${ }^{19}$ та ін.

I. Драч як митець з ознаками екстравертивності опоетизовує конкретні дати через посередництво числівникових форм. Точну дату смерті з указівкою не лише на рік, але й на день і місяць подають у поезії нечасто, тим паче з указівкою й на кількість років, що їх прожила особа. Очевидно, прагматика числа тут поєднується із прагматикою власної назви, що призводить до виникнення рефлексії, насиченої негативною оцінністю: Жоден бандерівецьь не злякав його навіть з рогатки... / Рейхскомісар Украйни Еріх Кох, / Нещадний фашист, «другий Сталін», / Помер у затишній польській тюрмі / 12 листопада 1986 року, маючи 92 роки... (Самообслуговування) $)^{20}$. У його текстах також домінують числівникові вираження конкретних подій, конкретного року, конкретної цифри загиблих: Там тих дев'ять загиблих мільйонів / 3 того тридцять третього року.... (Розмова з бабою історією) $)^{21}$; Тут чотирнадцять тисяч зотліло, / Під твої ж кулемети лягло, / В жовту квітку тепер проясніло / Кожне юне $і$ чисте чоло (Балада про чорну пам'ять) ${ }^{22}$.

Високочастотним у поетичних текстах I. Драча $\epsilon$ і числівник сто, що вказує на невизначено велику кількість, є засобом увиразнення простору і його об'єктів, часу: Ще ж роботонька не перероблена - ти ж так люто ї̈ робив, / Над столом ти перегинався, як обухівських сто горбів... (Андрію Малиику - на 60 років життя) ${ }^{23}$; Поки сльози випали, / То по чариі випили, / Йило сто літ чи сто гон, / Йили крізь сон на стадіон... (Соната Прокоф 'єва) $)^{24}$; В мого роду - cmo доріг, / Cmo cmoлімь у мого роду (Балада роду) ${ }^{25}$; Внучок тупц̧ю тупотить, / Тупц̧ю, внуц̧ю, тупџฺю, хлопче, / Сто стежин у світ летить, / Він - сто першеньку протопче... (Балада роду) ${ }^{26}$ та ін. На базі числівника сто поет моделює яскраві художні образи, використовуючи гіперболу, метафору й метонімію, напр.: Сто тисяч рік в одній ріці. / Сто тисяч рук в одній руц̧і. / I сто століть на кулац̧і. / Все спиш? Вставай! Грими! (Текучий меч) ${ }^{27}$.

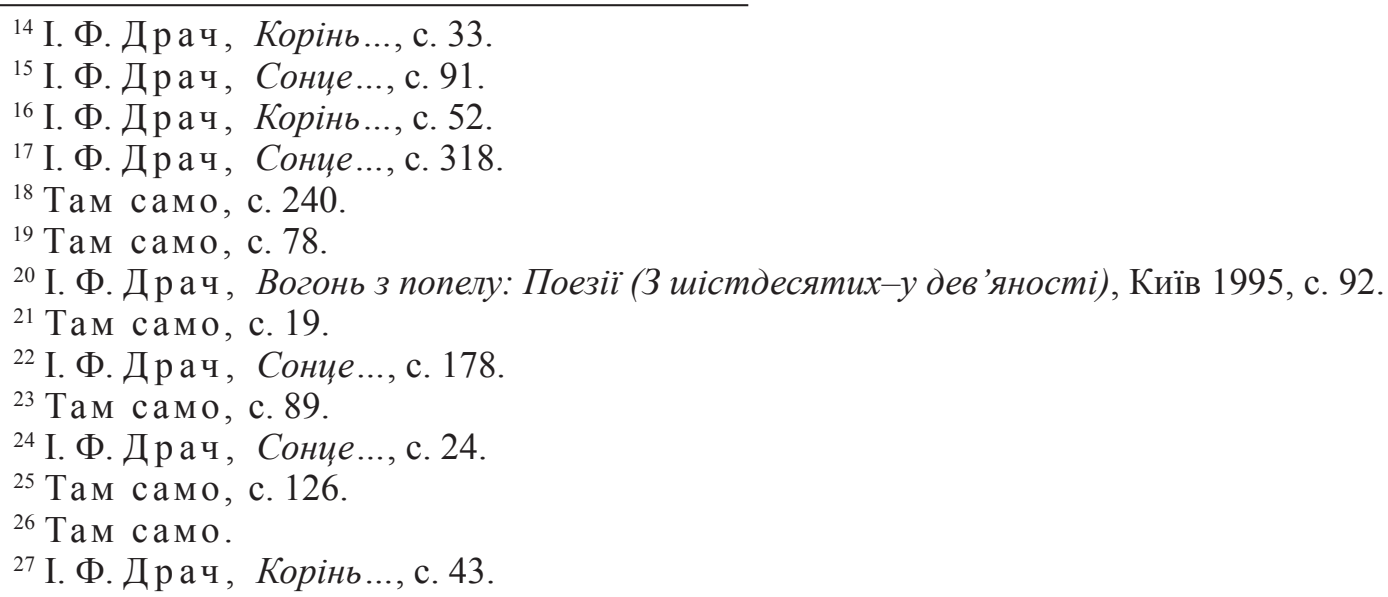


Поетичне мовлення Ліни Костенко теж характеризується значною кількістю числівникових слововживань, однак йому властиве абстрактне, а не конкретизоване сприйняття кількості. Кількість переважно є невизначеною, розмитою семантично, актуалізуються аксіологічні смисли, а також смисли, що вказують на внутрішнє “я”, самотність, індивідуалізм. На останньому наголошували й інші дослідники мовлення Л. Костенко, зокрема О. Зінченко і Т. Коляда ${ }^{28}$.

У iii поезії є улюблені числівники. Якщо зважати на кількісні показники слововживання, то до них можна віднести один, два, три, чотири, n'ять, сто, тисяча, що їх використовує поетеса частіше за інші. Саме вони репрезентують широку палітру різноманітних смислів.

Л. Костенко має особливу здатність відчувати світ через переосмислення категорії кількості, числа, порядку, що дають їй змогу репрезентувати не лише зовнішній світ, але передусім світ внутрішній. У іiі текстах у багатьох випадках у числівників нейтралізується їхнє первинне значення, а семантика кількості зовсім зникає, напр., у числівника один залишається лише його форма, натомість актуалізуються займенникові смисли дейктичності, що виражають відповідний ступінь інтимізації, чи прикметникові смисли ознаки, якості, оцінки. Слово один посідає особливе місце в системі числівника за своїми семантичними й прагматичними потенціями.

Цей числівник досить послідовно в поетичних текстах Л. Костенко виражає властиву йому семантику “иілісності, єдності, нероздільності": $A$ я вже, Грицю, їден дух з тобою, / Хай ми вже й тілом будемо одне... (Маруся Чурай) ${ }^{29}$, порівн. також: I ось лежить. Нема кому стулить / Його в одне на плитах базиліки... / Прокинувся. Нічого не болить (Берестечко) $)^{30}$ та ін. Частотною для числівника один є й реалізація смислу “єдиний”, “неповторний”: А суддям я таку даю нагану: / Щоб наперед без відома мого / Не важились на страти самочинні, / Передовсім освідчили мене / Про кожну страту, по такій причині, / Що смерть повсюди, а жсиття одне... (Маруся Чурай) ${ }^{31}$, Ох, у житті свобода лиш єдина, / Одна свобода - та, щзо у мені! (Берестечко) ${ }^{32}$; О ким я був $і$ ким зробився нині! / Куди подів життя своє одне? (Берестечко) ${ }^{33}$.

На базі числівника один поетеса утворює словотвірну модель один-єдиний, що інтенсифікує вираження відповідного смислу одиничності, мізерності: ... Один-сдиний дотик абсолютного — моя душа відкрилась, як Сезам (Божевілля моє, божемилля) $)^{34}$; тепер хоча б одна-єдина хатка! (Берестечко) $)^{35}$.

Смисл “високий ступінь самотності”, “наявність непорозуміння”, “відсутність щзирих почуттів”, що яскраво характеризує настрій особистостей інтровертивного характеру, до яких, припускаємо, належить і Л. Костенко, породжується й завдяки поєднанню числівникової форми одні з відчислівниковим прислівником удвох - удвох одні, порівн.: Одвірок за ніч замерзає в сінях. / Стоять в кутку забуті рогачі. / Перелузали зиму, як насіння, / Удвох одні

${ }^{28}$ В. В. Акуленко, С. А. Швачко, Е. И. Бекреева, Категория количества в современных европейских языках, Київ 1990, 284 с.

${ }^{29}$ Л. Костенко, Поезї, [в:] Ліна Костенко, Олександр Олесь, Василь Симоненко, Василь Стус: збірка, Київ 1998, с. 53.

${ }^{30}$ Л. В. Ко ст ен ко, Берестечко. Київ 1999, с. 7.

31 Л. Косте нко, Поезії..., с. 89.

32 Л. В. Ко с т енко, Берестечко..., с. 87.

${ }^{33}$ Там само, с. 108.

${ }^{34}$ Л. Ко с тенко, Над берегами вічної ріки: Поезії, Київ 1977, с. 142.

35 Там само, с. 104. 
на тій-таки печі (Маруся Чурай) ${ }^{36}$. Механізм породження цього смислу базується на несумісності синтаксичного зв'язку названих лексем з урахуванням їхнього прямого значення, вказівки на відповідну кількість. Породження подібного смислу простежуємо і в прикладі, де змальовується відчуття одинокості серед людей, юрби: Я ішла за тобою одна у юрбі. / Oт і всі твої, мамо, i діти, $i$ внуки (Маруся Чурай) $)^{37}$; - У мене син одинчичок, панове, / I запечалля на душі одне, / Одна у сериі шпичечка тернова, — / Не дай же Бог, у прийми дремене! $(\text { Маруся Чурай })^{38}$. В останньому прикладі прагматичне навантаження числівникової форми один посилюється тим, що поряд у контексті вжито дериват саме цього числівника із суфіксом суб'єктивно-оцінної семантики, що виражає пестливе ставлення, почуття любові (одинчичок). Такі утворення характерні для поезії Л. Костенко, причому гама демінутивних суфіксів максимально використана: А я думав: - Сестричко! Доненько! / Ну, врятував я тебе, однісіньку... (Берестечко $)^{39}$; Чуєш, роде мій, мій ріднесенький, / Хоч би вийшов хто хоч однесенький.... (Чоловіче мій, запрягай коня!) ${ }^{40}$; Тут, може, ідеться про долю краӥни! — / А я про чиєсь там одненьке життя! (Маруся Чурай) ${ }^{41}$.

Числівник один послідовно й найбільш часто виражає в тексті поезії Л. Костенко як значення "одинокості”, “самотності”, так і “самостійності”, “індивідуалізму”, що близьке до значення, яке містить займенник сам. Це значення може стосуватися осіб чоловічої й жіночої статі: Яка самотність! 3 темрявою злився. / Мене нема. Я згарище. Я дим. / Проходив дощ, пошепотів із листям: / Та й знов нікого, знову я один (Берестечко) ${ }^{42}$; Убиті коні... потязі боліт... / I я один на всенький кругосвіт... (Берестечко) ${ }^{43}$; Прокинулась від крякання ворон. / Дашок дірявии, дошзана стіна. / Дяка нема. Тиша. Я одна (Маруся Чурай) ${ }^{44}$; Так сталося, і я тепер одна... (Маруся Чурай) ${ }^{45}$; Все так, як є. Приречена. Одна. / Стіна. Стіна. І грати. I стіна. (Маруся Чурай) ${ }^{46}$. Очевидно, це можна пояснити близькістю названого відчуття до інтровертивної свідомості поетеси, порівн.: Рано я, рано зосталась вдовою, / та й попливла, як лист за водою. / Живу одна, / живу, як черниия... (Мандрівки серия $)^{47}$; Чайки держаться гурту, / а ти відпливаєш одна... (Чайка на крижсині) ${ }^{48}$.

Для увиразнення значення стану “самотності”, вираження більшої інтенсивності його вияву поетеса вдається до редуплікації лексеми один, напр.: Він там живе в степу за вітряками, / Один-один, одвик $і$ говорить... (Маруся Чурай $)^{49}$; Пливуть над степом хмари волохаті. / Живе там якось, як уже не є. / Один-один. / I домовик у хаті / Сміється, плаче й руку подає... (Маруся Чурай) $)^{50}$.

Частотним $є$ й використання числівникової форми один для вираження прагматичних модальних смислів, що містяться в частках лище, тільки, саме,

\footnotetext{
36 Л. Ко стенко, Поезї̈.., с. 39.

37 Там само, с. 91 .

${ }^{38}$ Там само, с. 16.

39 Л. В. Костенко, Берестечко..., с. 20.

40 Л. Ко с те н ко, Неповторність: Вірші. Поеми, Київ 1980, с. 17.

${ }^{41}$ Л. Костенко, Поезї..., с. 178.

42 Л. В. Костенко, Берестечко..,, с. 108.

${ }^{43}$ Там само, с. 31.

44 Л. Костенко, Поезї..., с. 121.

45 Там само, с. 48.

46 Там само, с. 33.

47 Л. Ко с те н ко, Мандрівки серияя. Поезї, Київ 1961, с. 88.

48 Там само, с. 62.

49 Л. Ко с те нко, Поезї..., с. 37.

50 Там само, с. 134.
} 
які виконують у тексті видільну модальну функцію, напр.: I яблуня одна, нікому не підзвітна, / Хазяїна свого шукала навздогад (Зимовий етюд) ${ }^{51}$; Одне добре: / Де б він не був, / Вона чує, як б’ ється його серцее.... (Мандрівки серия $)^{52}$.

Числівник один може дублювати модальне значення вказівності, виокремлення, що його вже містить частка тільки. А це відповідно увиразнює текст: І тільки одна чорнокоса ж⿻інка / Між цчих болящчих звучить дисонансом ... (Пансіонат “Форель") $)^{53}$.

Окремі вірші насичені низкою числівників, що вказують на невизначений конкретно час, напр.: Як рік, $\boldsymbol{i}$ два, $і$ три тому, $\boldsymbol{i}$ n'ять. / Стоять ті польські консистенти, / Постоєм стали $і$ стоять (Берестечко) ${ }^{54}$, навіть спроба подати уточнення не позбавляє текст невизначеності, порівн.: Давно, / Iице в шістсот якомусь році, / Ну, цеебто більш як три віки тому, / Коли носили шпаги ще при бойі / I розважали стратами юрму... (Кольорові мимі) ${ }^{55}$. Зазначене стосується й порядкових числівників - Все винен я. За все. У всьому. / Не штука битву розпочати. / I першу битву, й другу, й сьому, — / Все мусив я передбачати (Берестечко $)^{56}$.

Л. Костенко за допомогою числівника сто концептуалізує час, простір, а також буття людини. Безумовно, конкретне значення кількості, що його містить у первинній функції числівник сто, тут нейтралізується. Для інтроверта Л. Костенко характерний непрямий порядок слів, що підкреслює невизначеність кількості, її приблизність: У раю сидів я, дуже я занидів, / Бо вже України років сто не видів (Маруся Чурай) ${ }^{57}$; А так усі розплутують по вузлику, по ниточuүi, / Вжке років сто розплутують усе, щзо ти плела (Віяло мадам Полетики) ${ }^{58}$.

Така невизначеність великої кількості стосується й буденної людської онтології - На сто думок замислена Полтава / Вербові гриви хилить до води (Маруся Чурай) ${ }^{59}$; А там, а там, а там!.. / Труснем цичганську грушу — / Та й буде урожай, ще сто таких, як ти... (Циганська муза) $)^{60} ;$ У нього сто таких на Берестові, / I кожна з них заходиться плачем, — / Бо князь розлюбить, то уже любові / Ні слізьми не повернеш, ні мечем (Горислава-Рогніда) ${ }^{61}$. Велика невизначена кількість (сто) зіштовхується у контексті Л. Костенко із унікальністю, виокремленістю одного, що підвищує високий статус цього одного, що характерно для інтровертів, причому зміна порядку слідування одного і $\mathrm{cma}$ в межах відповідних виразів актуалізує різні смисли, напр.: Його убили - сто на одного! / Війна - це тир, де цілий світ - мішені (У Медвині, де київські князі... ${ }^{62}$; На сто одна. Це, зрештою, природно. / О Маргарити кольору бордо. / Натхнення? Що ви? Зараз цее не модно. / Цікаво, як співала Віардо? (Сольфеджсіо) ${ }^{63}$.

Перераховані смисли, що є частотними в текстах Л. Костенко, вказують, що за допомогою числівникових форм вона омовлює складний внутрішній світ лю-

${ }^{51}$ Л. Костенко, Мандрівки серияя..., с. 98.

${ }^{52}$ Там само, с. 72.

53 Л. Кос те н ко, Неповторність..., с. 193.

54 Л. В. Ко ст енко, Берестечко..., с. 87.

55 Л. Косте нко, Неповторність..., с. 148.

56 Л. В. Ко с тен ко, Берестечко.., с. 79.

57 Л. Косте нко, Поезї..., с. 100.

58 Л. Ко с т е н ко, Сад нетанучих скульптур: Віриі. Поема-балада. Драм. Поеми, Київ 1987, с. 40.

${ }^{59}$ Л. Косте нко, Поезї..., с. 30.

${ }^{60}$ Л. Ко с те н ко, Неповторність..., с. 208.

${ }^{61}$ Там само, с. 153 .

${ }^{62}$ Там само, с. 191.

${ }^{63}$ Л. Ко с те н ко, Над берегами..., с. 89. 
дини; ці смисли демонструють прагнення зануритися в себе, людську внутрішню природу, почуття, емоції, психологічні стани, що є властивим для інтроверта.

Як показує проаналізований матеріал, лексико-граматичний клас числівників виразно виокремлюється в мовній картині світу І. Драча і Л. Костенко, репрезентуючи найрізноманітніші смисли. Поетичні тексти демонструють, що в кожного з поетів серед числівникових форм є свої „фаворити”, які актуалізують різні аксіологічні смисли, що підтверджує приналежність поетів до відповідних психологічних типів - екстравертів й інтровертів.

Перспективу дослідження вбачаємо в необхідності аналізу інших лінгвальних одиниць, що репрезентують мовні особистості, основою яких є віднесеність до різних психотипів. 